\title{
Europe's parliament loses reputation
}

The decision of the Strasbourg parliament to throw out a draft directive on genetic manipulation will do less harm to biotechnology than to the parliament itself.

Ever since the Maastricht Treaty was eventually ratified at the end of 1993, the European Parliament has been walking taller, flexing its muscles and looking forward to the increased influence it is promised by the treaty. There are good reasons to welcome that development. The smaller members of the European Union (EU) naturally see the parliament as a valuable counterpoise to the power of the Council of Ministers (where big countries have more votes) and the European Commission, but even the German government has been a consistent advocate of more influence for the parliament, apparently on the self-denying grounds that a democracy needs an effective parliament. So, until last week, the wind seemed to be at Strasbourg's back. And then the European Parliament, in a rush of blood to the head, threw away its reputation for good sense and probity.

It is an extraordinary story (see page 103). The Commission has been struggling with the Council of Ministers for two years to devise a directive on the patentability of innovations in human, animal and plant genetics. As things stand, there is a European Patent Office (EPO) established by treaty and national legislation that reflects EPO's charter, even down to the provision that inventions should not be awarded if they are contrary to the ordre publique, a French concept loosely translated as unseemly and immoral.

The past few years have thrown up a host of conundrums with which patent examiners must contend, often for the first time. Are 'expressed sequence tags' patentable? Does the legitimate protection afforded to the discovery of a significant mutation in a single gene (which might become the basis of a diagnostic test) give the patent-holder the right to exploit all other mutations of the same gene? What kinds of rights does a genetic manipulator acquire over the progeny of genetically engineered plants and animals that may be sold to farmers?

The Commission's draft directive sought to clarify many of these issues, mostly uncontentiously. Partial DNA sequences should not be patentable unless they have direct utility, for example. But in the patenting of genetically modified animals (plants are dealt with differently), the test should be whether "a substantial benefit to man or animal" should offset "suffering or physical handicap" to the animals. In short, the directive is not a charter for those who would engage in genetic manipulation designed to give the European public an attack of horrors, but rather is a mildly restrictive clarification of present practice. But against rea- son, and the odds, the parliament threw out the directive as a whole. It would have none of it.

This sombre incident says more about the European Parliament than about the present or future practice of genetic manipulation in Europe. Since its inception, the parliament has been notoriously susceptible to the influence of pressure groups, at the outset because its members needed the help that pressure groups could provide, latterly because they have become familiar. The parliament is also given to gusts of emotional reaction, which hitherto have mattered little because its role was advisory only. But now the Commission will have to pay attention to the parliament's vote. Certainly, important questions will be delayed. No doubt there will be a further round of negotiations and further compromise.

On reflection, wiser heads in Strasbourg (where the parliament spends some of its time) will conclude that this latest show of political correctness has been an act of irresponsibility, as if it were a parliament demanding social programmes from its government while refusing to sanction the taxes with which to pay for them. The point is all the more telling because the parliament has an ambition (and a right under Maastricht) to have an influence on the development of European foreign and security policy, both of them fields of public policy in which an element of realism is inseparable from success. On last week's form, it can be only a matter of time before Strasbourg is voting for the abolition of armed forces on the grounds that their members are equipped with munitions, which are dangerous. $\square$

\section{Unbalanced US budgets}

There should be relief that the new US Congress has failed to pass its talismanic constitutional amendment.

THE United States is lucky that the famous Balanced Budget Amendment, a central part of the Republican Party's Contract with America, failed to pass the Senate last week. In reality, the whole project is a recipe for disaster. Last Friday, even The Wall Street Joumal acknowledged that the project has been largely a symbolic issue, a promise to voters that politicians would never again be spendthrift with their money. But it is worse than that. Either the promise would have been hollow in the sense that politicians would have found ways around it, or it would have led to spending 